Sakharov visits US to

launch international group

- Perestroika under domestic threat

- Sakharov's first visit to the West

Boston

Soviet physicist and dissident Andrei

Sakharov embarked on his first visit to the

West last week to help launch a new international foundation. This week he is scheduled to meet President Reagan at the White House, and on Wednesday is due to meet for the first time Edward Teller at a reception in Washington.

In his remarks to a large gathering of scientists and reporters at the American Academy of Arts and Sciences in Cambridge, Massachusetts, the 67-year-old recipient of the 1975 Nobel Peace Prize spoke positively about perestroika but also warned of domestic threats which could cripple newly established Soviet freedoms.

Perestroika is not "theatre for the West", Sakharov said, but is an "extraordinarily serious" process which is now in an "acute phase". The Western world, said Sakharov, should not fear perestroika's success, but rather its failure. Such a failure, Sakharov warned, would lead to "external expansion" by the Soviet Union, a "strengthening of repressive organs" in the country.

Sakharov's visit marked the official start in the United States of the International Foundation for the Survival and Development of Humanity, the first international, non-profit organization to be based in the Soviet Union. The foundation, which has established offices in Moscow, Stockholm and Washington, DC, plans to make grants for collaborative international projects in the areas of arms control, environmental protection, international development, energy and human rights, and, according to Sakharov, to "take a role in the global problems now standing in front of humanity".

Along with prominent Soviet scientists Yevgenii P. Velikhov and Roald Sagdeev, Sakharov will spend approximately three weeks in the United States to help promote the fledgling international organization and to convene its first board meeting with members from eighteen nations. The organization, which has preliminary funding from the Soviet Union and from Armand Hammer, 90-year-old chairman and Chief Executive Officer of Occidental Petroleum, plans to begin funding proposals soon after 1 January 1989.

Velikhov, the chairman of the foundation's executive committee, and vicepresident of the Soviet Academy of Sciences, told the gathering that problems of the environment, disarmament and the biosphere "do not belong to any one country" and that this realization formed the "groundwork" for establishing the foundation. Sakharov's presence, he said, was an indication of the Soviet Union's current commitment to the "freedom of ideas".

Sakharov was allowed to leave the Soviet Union under a provision of a law passed one month ago which allows international foundations to exist within the Soviet Union and includes a provision permitting Soviet board members to attend foundation meetings.

Jerome Weisner, vice-chairman of the foundation's executive committee and president emeritus of Massachusetts Institute of Technology, stressed the need for many nations to involve themselves in the foundation's work. Other foundation board members include former US Secretary of Defense Robert McNamara, John Sculley, Chief Executive Officer of Apple Computers, and representatives from Japan, China and many European countries.

At the press conference to launch the foundation, Sakharov, in his first public appearance in the West, fielded a wide range of questions from reporters in which he condemned the Soviet Union's cessation of withdrawal of their troops from Afghanistan and called for UN intervention in that conflict. He also expressed his views that space-based defence initiatives like the US Strategic Defense Initiative are "very destabilizing" and "completely senseless from an economic point of view". Many of his remarks, however, were devoted to his concerns about "extremely dangerous" recent laws in the Soviet Union that threatened perestroika by limiting people's freedom of association and demonstration and by centralizing authority within the Soviet ministry of internal affairs, creating, he said, a situation of virtual "martial law".

In addition, Sakharov, who was banished to the closed city of Gorky in January 1980 after calling for the withdrawal of Soviet troops from Afghanistan, said that it is "vital to succeed in freeing all prisoners of conscience" and stressed that many in the Soviet Union were still being held for their religious and political beliefs. Among such prisoners still being held captive in the Soviet Union, according to Sakharov: Vazif Meylanov, Yuri Badzyo, Levko Lukyanenko, in internal exile in Siberia, and Boris Mityashiv, Mikhail Kukobaka and Mikhail Alekseev, in labour camps or prisons. Seth Shulman

\section{Science gap growing}

THE gap between Soviet and Western science is still growing, Dr Nikolai Laverov, one of the five new vice-presidents of the Soviet Academy of Sciences, says in Izvestiya. The gap is particularly apparent, he says, in the lack of state-of-the-art instruments for academy institutes, in the mathematical modelling of geophysical and geochemical processes, in the study of mineral ores and in oceanography and seafloor studies. Laverov was elected last month as vice-president responsible for Earth sciences, in place of Dr Alexsandr Yanshin, who resigned the post under the academy's new compulsory retirement policy.

V. R.

\section{New museum director}

THE British Museum (Natural History) has a new director. Dr Neil Robert Chalmers has taken over from Dr Ron Hedley, who had held the post for $\mathbf{1 2}$ years and has now retired. Chalmers studied zoology at the universities of Oxford and Cambridge and has worked at the Makerere University College, Uganda, the National Primate Centre, Kenya, and the Open University in Britain. The director's appointment is for an initial period of five years. $\quad$ C. McG.

\section{Latest NIH institute}

THE National Institute of Deafness and Communication Disorders became the thirteenth and newest institute of the National Institutes of Health (NIH) earlier this month. NIH associate director Jay Moskowitz will be acting director of the institute until a permanent director is found. The institute is authorized to spend up to $\$ 96.1$ million in its first year, with funds administered through the National Institute of Neurological and Communicative Disorders and Stroke at the discretion of the Secretary of the Department of Health and Human Services.

J. P

\section{Backing basic research}

WITH no relief from the Australian government, Mr Barry Jones, the Minister for Science, Customs and Small Business, is trying to establish a privately backed investment fund for basic research. Jones had chief responsibility for science until a major ministerial reorganization last year.

Jones hopes that 10-20 large corporations will contribute up to $\mathrm{A} \$ 100$ million each to the fund over ten years and has approached several industry leaders for discussions. Tax exemptions could provide an incentive to invest. Jones has been highly critical of Australia's failure to make long-term investments in new technology although he recognizes that the prime minister and government have to deal with more pressing economic problems. ". . . This is not the time to engage them in discussion about the long-term future ..." he says. 